\title{
Modulation of Basal Nitric Oxide-dependent Cyclic-GMP Production by Ambient Glucose, Myo-Inositol, and Protein Kinase C in SH-SY5Y Human Neuroblastoma Cells
}

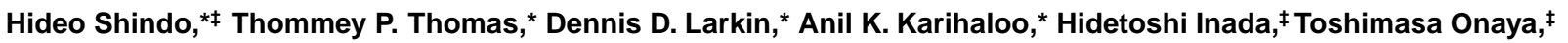 \\ Martin J. Stevens, ${ }^{*}$ and Douglas A. Greene* \\ *Division of Endocrinology and Metabolism, Department of Internal Medicine, and Michigan Diabetes Research and Training Center, \\ University of Michigan, Ann Arbor, Michigan 48109: and ${ }^{\ddagger}$ Third Department of Internal Medicine, University of Yamanashi Medical \\ School, Tamaho, Yamanashi-ken 409-38, Japan
}

\begin{abstract}
Defective tissue perfusion and nitric oxide production and altered myo-inositol metabolism and protein kinase $\mathrm{C}$ activation have been invoked in the pathogenesis of diabetic complications including neuropathy. The precise cellular compartmentalization and mechanistic interrelationships of these abnormalities remain obscure, and nitric oxide possesses both neurotransmitter and vasodilator activity. Therefore the effects of ambient glucose and myo-inositol on nitric oxide-dependent cGMP production and protein kinase $\mathrm{C}$ activity were studied in SH-SY5Y human neuroblastoma cells, a cell culture model for peripheral cholinergic neurons. D-Glucose lowered cellular myo-inositol content, phosphatidylinositol synthesis, and phosphorylation of an endogenous protein kinase $C$ substrate, and specifically reduced nitric oxide-dependent cGMP production a time- and dosedependent manner with an apparent $\mathrm{IC}_{50}$ of $\sim 30 \mathrm{mM}$. The near maximal decrease in cGMP induced by $50 \mathrm{mM}$ D-glucose was corrected by the addition of protein kinase $\mathrm{C}$ agonists or $500 \mu \mathrm{M}$ myo-inositol to the culture medium, and was reproduced by protein kinase $\mathrm{C}$ inhibition or downregulation, or by myo-inositol deficient medium. Sodium nitroprusside increased cGMP in a dose-dependent fashion, with low concentrations $(1 \mu \mathrm{M})$ counteracting the effects of $\mathbf{5 0}$ $\mathrm{mM}$ D-glucose or protein kinase $\mathrm{C}$ inhibition. The demonstration that elevated D-glucose diminishes basal nitric oxide-dependent cGMP production by myo-inositol depletion and protein kinase $C$ inhibition in peripheral cholinergic neurons provides a potential metabolic basis for impaired nitric oxide production, nerve blood flow, and nerve impulse conduction in diabetes. (J. Clin. Invest. 1996. 97:736745.) Key words: diabetes $\bullet$ diabetic neuropathy $\bullet$ myo-inositol $\bullet$ protein kinase $\mathrm{C} \cdot$ nitric oxide
\end{abstract}

Address correspondence to Douglas A. Greene, 3920 Taubman Center, Box 0354, University of Michigan Medical Center, 1500 E. Medical Center Drive, Ann Arbor, MI 48109-0354. Phone: 313-936-5505; FAX: 313-936-9240; E-mail: dgreene@uv1.im.med.umich.edu

Received for publication 17 May 1995 and accepted in revised form 20 November 1995.

J. Clin. Invest.

(C) The American Society for Clinical Investigation, Inc.

0021-9738/96/02/0736/10 \$2.00

Volume 97, Number 3, February 1996, 736-745

\section{Introduction}

Nitric oxide (NO) is a highly reactive, rapidly diffusible gas synthesized from L-arginine by tissue- and cell-specific nitric oxide synthases $(\mathrm{NOS})^{1}(1,2)$. The calcium-calmodulin-dependent "constitutive" NOS isoforms in neuronal (ncNOS) and vascular endothelial cells (ecNOS) produce low levels of NO which specifically interact with and activate heme-containing soluble guanylyl cyclase in neighboring neuronal and smooth muscle cells respectively in a paracrine fashion $(1,2)$. Fold higher levels of NO produced by the calcium-calmodulin-independent, cytokine-"inducible" isoform (iNOS) in macrophages and vascular smooth muscle cells also nonspecifically interact with and chemically modify proteins and DNA, thereby mediating cytokine-induced cytotoxicity (3). In both concentration ranges, NO functions as a potent vasodilator, at low levels modulating vascular tone as the "endothelial-dependent relaxing factor" (4), and at high levels mediating endotoxic shock (1-3). Similarly, in the nervous system, low levels of NO mediate neurotransmission while high levels mediate neurotoxicity $(3,5)$. Cholinergic neurons employ $\mathrm{NO}$ as a retrograde inhibitory neurotransmitter (5), which, in sympathetic ganglia, could importantly modulate blood flow in tissues devoid of local vascular autoregulation such as peripheral nerve (6).

Both NO deficiency (7-13) and excess (14) have been invoked in the pathogenesis of chronic diabetic complications. Glomerular NO deficiency has been linked to glomerular hypertension in the diabetic rat (11) and ascribed to activation of protein kinase C (PKC) by D-glucose-derived diacylglycerols (DAGs) and/or to overproduction of thromboxanes (12). In diabetic rat peripheral nerve, NO deficiency has been hypothesized to reflect competition for NADPH cofactor by NOS and aldose reductase (AR), which is activated by D-glucose substrate in hyperglycemic states (13). Alternatively, inhibition of nerve PKC activity, which is attributed to D-glucoseinduced depletion of myo-inositol (MI) and arachidonyl DAG,

1. Abbreviations used in this paper: $\mathrm{AR}$, aldose reductase, CDP-DG, cytidine-diphosphodiglyceride; DAG, diacylglycerol; $\mathrm{DiC}_{8}$, dioctanoylglycerol; ecNOS, endothelial constitutive nitric oxide synthase (NOS isoform III); IBMX, 3-isobutyl-1-methylxanthine; iNOS, inducible nitric oxide synthase (NOS isoform II); L-NAME, $\mathrm{N}^{\omega}$-nitro-Larginine; MARCKS, myristoylated alanine-rich C-kinase substrate; MI, myo-inositol; NOS, nitric oxide synthase (EC 1.14.13.39); nc-NOS, neural constitutive nitric oxide synthase (NOS isoform I); PI, phosphatidylinositol; PKC, protein kinase C; RPE, retinal pigment epithelial; SHTE, selenium hydrocortisone, transferrin, and estradiol; SNP, sodium nitroprusside; TPA, 12-O-tetradecanoyl-phorbol-13-acetate. 
could underlie NO deficiency and/or reduced blood flow in diabetic nerve (15-20). Cultured mouse neuroblastoma cells exhibit D-glucose-induced MI depletion $(21,22)$ and NO-mediated cGMP production $(23,24)$. Hence, human SH-SY5Y neuroblastoma cells provide a well-characterized, readily available cholinergic neuronal model to investigate further the relationship between ambient D-glucose concentration, MI depletion, PKC activity, and NO in human nerve cells. The experiments reported in this communication suggest that D-glucose inhibits neuronal NO in SH-SY5Y cells and does so at least in part through MI depletion and inhibition of $\mathrm{PKC}$, thereby implicating this putative metabolic pathway of neural glucose toxicity in NO-mediated neural dysfunction and/or impaired neurally regulated nerve blood flow.

\section{Methods}

Dulbecco's minimal essential medium (DMEM), HBSS, trypsinEDTA, and commercial assay-kits for PKC and cGMP were purchased from GIBCO BRL (Grand Island, NY) and Amersham International Corp. (Arlington Heights, IL), respectively. Bovine calf serum (BCS) was purchased from Hyclone Labs (Logan, UT). D-Glucose, L-glucose, mannitol, 3- $O$-methyl-glucose, $\mathrm{N}^{\omega}$-nitro-L-arginine (L-NAME), sodium nitroprusside (SNP), bicinchoninic acid, copper sulfate, 12-Otetradecanoyl-phorbol-13-acetate (TPA), dioctanoylglycerol $\left(\mathrm{DiC}_{8}\right)$, ATP, Triton X-100, saponin, SDS, dexamethasone, LPS, recombinant IFN- $\gamma$, and 3-isobutyl-1-methylxanthine (IBMX) were purchased from Sigma Chemical Co. (St. Louis, MO). Acrylamide, bis-acrylamide, ammonium persulfate and $N, N, N^{\prime}, N^{\prime}$-tetramethylethylenediamine (TEMED) were from Bio-Rad (Melville, NY), and $\gamma^{-32} \mathrm{P}$-ATP was from ICN (Costa Mesa, CA). Tissue culture supplies were purchased from Corning Glass Works (Corning, NY) and Costar Corp. (Cambridge, MA). Calphostin $\mathrm{C}$ was purchased from Kamiya Biomedical Co. (Thousand Oaks, CA). Griess Reagents were obtained from a commercial nitrite assay kit (Cayman Chemical Co., Ann Arbor, MI). GIBCO, Baker Chemical Co. (Phillipsburg, NJ), and Fisher Scientific Inc. (Fair Lawn, NJ) supplied other reagent grade chemicals.

Cell culture. SH-SY5Y cells (passage 70-85 kindly provided by Dr. Eva Feldman at the University of Michigan, Ann Arbor, MI) were grown in DMEM containing $10 \% \mathrm{BCS}, 100 \mathrm{U} / \mathrm{ml}$ penicillin, and $100 \mu \mathrm{g} / \mathrm{ml}$ streptomycin in humidified $10 \% \mathrm{CO}_{2}$ with media changed every 2-3 d. Cells were plated in 10-cm, or for PKC assay, $15-\mathrm{cm}$ dishes for $1 \mathrm{~d}$, and then exposed to various experimental conditions as indicated in text and figures. $5 \mathrm{mM}$ D-glucose served as the reference control. In selected experiments exploring the effect of MI-deficient medium, cells were cultured in serum-free DMEM supplemented with SHTE (30 $\mathrm{nM}$ selenium, $10 \mathrm{nM}$ hydrocortisone, $100 \mu \mathrm{g} / \mathrm{ml}$ transferrin, and $10 \mathrm{nM} \beta$-estradiol [25]) containing $5 \mathrm{mM}$ D-glucose and normal $(40 \mu \mathrm{M})$ or reduced $(0.1 \mu \mathrm{M}) \mathrm{MI}$.

Analytical techniques. Sorbitol and MI were quantitated by gasliquid chromatography of aldonitrile derivatives of cell extracts (26) and normalized to cell protein content. cGMP was measured in cells rinsed with PBS and homogenized in $65 \%$ ethanol by scintillation proximity RIA using a commercially available RIA kit and normalized to cell protein. Cytidine-diphosphodiglyceride (CDP-DG) was measured by liquid scintillation spectrometry after equilibrium labeling with $\left[5-{ }^{3} \mathrm{H}\right]$-cytidine, and extraction and separation by thin layer chromatography (24). Soluble and $0.5 \%$ Triton X-100-solubilized membrane-associated PKC activity was measured in cytosolic and particulate fractions $\left(10^{5} \times \mathrm{g} \times 0.5 \mathrm{~h}\right)$ as incorporation of $\left[{ }^{32} \mathrm{P}\right]$-ATP $(\sim 0.2 \mu \mathrm{Ci} / \mathrm{nmol})$ into a synthetic PKC-specific peptide substrate (Ac-MBP:4-14) using PKC:19-36 (a PKC pseudosubstrate inhibitor) to correct for nonspecific phosphorylation (27). Phosphorylation of the myristoylated, alanine-rich C-kinase substrate protein (MARCKS) was assessed in cells labeled with ${ }^{32} \mathrm{P}$-orthophosphate for $2 \mathrm{~h}$ and lysed in buffer containing $0.5 \%$ Triton X-100 and $0.5 \mathrm{mg} / \mathrm{ml}$ saponin (28). Nuclei were removed by centrifugation $(9000 \mathrm{~g} \times 2 \mathrm{~min})$, and proteins from the detergent soluble supernatant $(0.8 \mathrm{ml})$ collected at the interface of a methanol-chloroform extraction $(4: 1)$, solubilized in buffer containing 2\% SDS, quantitated using bicinchoninic acid (29), and incubated with $40 \%$ acetic acid. The MARCKS-containing supernatant was separated by SDS-PAGE and assayed for ${ }^{32} \mathrm{P}$ in a phosphorimager. $\mathrm{NO}_{2}$ content was measured in $100 \mu \mathrm{l}$ aliquots of phenol red-free culture media by the addition of $50 \mu$ l each of Greiss Reagent- 1 and Greiss Reagent- 2 as absorbency at $540 \mathrm{~nm}$ after 15 min, with a standard curve generated by $0-50 \mu \mathrm{M} \mathrm{NaNO}_{2}$ (30). Total cell protein was measured using bicinchoninic acid (29). The presence of ncNOS and iNOS expression in SH-SY5Y cells was explored by reverse-transcriptase (RT)-PCR using specific oligonucleotide primers for human ncNOS (sense 5'-TGTGGTCACCAGCACCTTTG-3', antisense 5'-GGTGGCGTGGTGATGTCCAG-3', spanning bases 2424-3326 of the coding region) and iNOS (sense 5'-TCCAAATCTTGCCTGGGGTC-3', antisense 5'-TCAACGACAGCCTGGTCTTTCC-3', spanning bases 540-1435 of the coding region) (31-34). First-strand cDNA was reverse transcribed at $40^{\circ} \mathrm{C}$ for $1 \mathrm{~h}$ from $1 \mu \mathrm{g}$ total SH-SY5Y RNA in $50 \mu \mathrm{l}$ using $3 \mu \mathrm{g}$ oligo-dT, $1 \times$ reverse transcription buffer, RNAsin (Promega, Madison, WI), and avian myoblastosis virus reverse transcriptase (Boehringer Mannheim Biochemicals, Indianapolis, IN). PCR was performed on $5 \mu$ l of reverse transcribed product in a $100 \mu \mathrm{l}$ volume using Amplitaq (Perkin Elmer, Branchburg, NJ) and the products resolved on a 5\% polyacrylamide gel and visualized by ethidium bromide.

Statistics. Results are mean \pm SE. As specified in the text and figure legends, when statistical analysis was performed on replicate measures within a single experiment, the results were confirmed in one or more independent experiments. Statistical significance of differences among groups was analyzed by Student-Neuman-Keuls test, with significance defined as $\alpha<0.05$.

\section{Results}

The presence of 5-50 $\mathrm{mM}$ D-glucose in the culture medium had no readily apparent effect on cell growth rate or attained cell density after 4-6 d, e.g., SH-SY5Y cells seeded at an initial density of $0.55 \times 10^{6} / 10-\mathrm{cm}$ dish and grown in the presence of 5 or $50 \mathrm{mM}$ D-glucose for $4 \mathrm{~d}$ attained total protein masses of $1.18 \pm 0.05$ and $1.09 \pm 0.04 \mathrm{mg} /$ dish respectively $(n=5, P=\mathrm{NS})$ with no obvious morphological differences. Growth was noticeably slower at 100 or $300 \mathrm{mM}$ D-glucose, with initially higher plating densities of $0.7 \times 10^{6}$ and $2.9 \times 10^{6} / 10-\mathrm{cm}$ dish yielding nearly identical protein masses at $4 \mathrm{~d}$ of $1.31 \pm 0.05$ and $1.38 \pm 0.06 \mathrm{mg} /$ dish $(n=5, P=\mathrm{NS})$.

Effect of D-glucose on sorbitol, MI, phosphoinositide synthesis, and PKC. SH-SY5Y cells cultured in 50-100 mM D-glucose for $6 \mathrm{~d}$ exhibited osmotically trivial increases in sorbitol content (35) (Fig. $1 \mathrm{~A}$ ), and modest decreases in MI content (to 82 and $62 \%$ of the $5 \mathrm{mM}$ D-glucose control for 50 and 100 mM D-glucose, respectively, $P<0.05$ ) (Fig. $1 B$ ). Cellular MI depletion was neither produced by equimolar concentrations of nonmetabolized glucose analogues, e.g., mannitol (Fig. 1, shaded bars), nor prevented by the AR inhibitor sorbinil (Fig. 2). The MI depletion induced by D-glucose rendered MI rate limiting for phosphatidylinositol (PI) synthesis as evidenced by accumulation of CDP-DG, the cosubstrate with MI for PI-synthase (Fig. $1 C$ ). These findings are considered indicative of PI synthase inhibition by mass action secondary to MI depletion in other cells and tissues exposed to elevated ambient D-glucose levels $(17,19,26)$. Exposure to $50 \mathrm{mM}$ D- (but not L-) glucose for $6 \mathrm{~d}$ decreased both membrane-associated PKC 

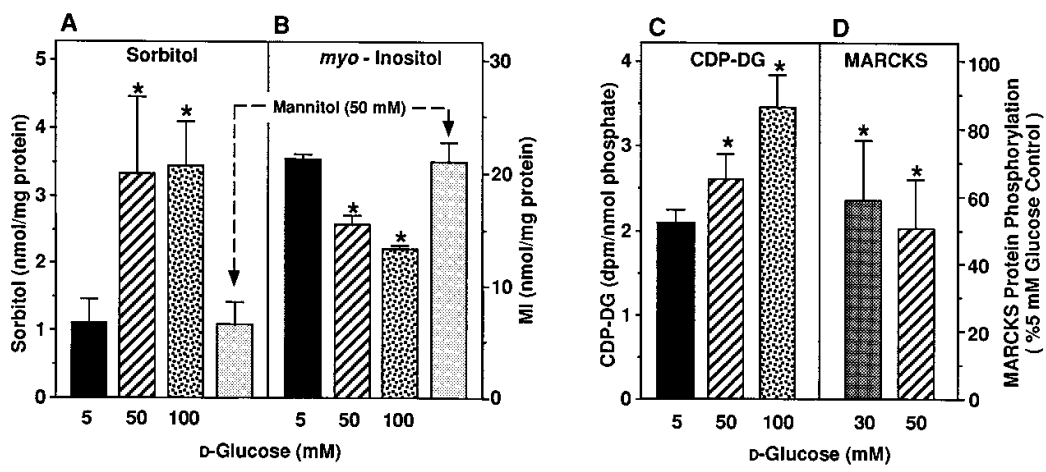

Figure 1. Effect of D-glucose on sorbitol, MI, CDPDG, and MARCKS phosphorylation in SH-SY5Y cells. Cells were cultured in 5-100 mM D-glucose (or $50 \mathrm{mM}$ mannitol as an osmotic control) for 5-6 d and processed for determination of sorbitol, MI, CDP-DG $(n=4$ replicate measures within a single experiment, confirmed in an independent experiment), and endogenous MARCKS phosphorylation $(n=3$ independent experiments; L-glucose results not shown) as described in Methods. ${ }^{*} P<0.05$ vs. respective $5 \mathrm{mM}$ D-glucose controls.

activity $^{2}$ and the phosphorylation of MARCKS, a specific endogenous PKC substrate (Fig. 1D) (28). Diminished MARCKS phosphorylation after $6 \mathrm{~d}$ could not be attributed to PKC downregulation after a putative transient initial increase in PKC activity induced by D-glucose (as described in various nonneural cells [36-41]) since MARCKS phosphorylation was not increased $2 \mathrm{~h}$ and $24 \mathrm{~h}$ after exposure to $50 \mathrm{mM}$-glucose (data not shown). Thus in SH-SY5Y cells cultured in elevated levels of D-glucose, flux through AR was low relative to sorbitol clearance, MI depletion was primarily non-AR mediated perhaps by competitive inhibition by D-glucose of Na-MI cotransport (42-44), depletion of MI limited basal PI synthesis $(7,19,26,45)$, and basal PKC-mediated MARCKS phosphorylation was reduced (19).

Effect of D-glucose on cGMP production. The cGMP content of SH-SY5Y cells increased progressively over $7 \mathrm{~d}$ when subcultured in $5 \mathrm{mM}$ (Fig. 3, solid circles) but not $50 \mathrm{mM}$ (Fig. 3 , open triangles) D-glucose, leaving cGMP levels significantly lower in 5 vs. $50 \mathrm{mM}$ D-glucose after 2, 4, and $7 \mathrm{~d}$. This effect of D-glucose on cGMP was concentration dependent, with an apparent $\mathrm{IC}_{50}$ of $\sim 30 \mathrm{mM}$ and near maximal inhibition at $50 \mathrm{mM}$ (Fig. 4, open circles); it was not reproduced by equimolar concentrations of the nonmetabolizable glucose analogue L-glucose, 3-O-methylglucose, or mannitol (Fig. 4), or by the alternate glycolytic substrate fructose (data not shown). This D-glucose effect was demonstrable at hyperglycemic concentrations found in experimental diabetes (e.g., $30 \mathrm{mM} \mathrm{D-glucose}$ [13]) and, at the near maximal D-glucose inhibitory concentration of $50 \mathrm{mM}$, reflected altered cGMP production rather than degradation since it persisted in the presence of $500 \mu \mathrm{M}$ IBMX, a phosphodiesterase inhibitor (46) (Fig. 4, inset). These data suggest that altered metabolism of D-glucose after brief exposure to hyperglycemic ( $30 \mathrm{mM}$ [13]) levels impairs basal cGMP production.

Effects of NOS inhibition and NO agonists on cGMP. The NOS inhibitor L-NAME was used to determine if basal

2. Cytosolic and membrane-associated PKC activities were measured in cells cultured in 5 and $50 \mathrm{mM}$ D-glucose for $6 \mathrm{~d}$. Cytosol activity was unaffected by $50 \mathrm{mM}$ D-glucose $(96.9 \pm 9.2 \%$ of control, $n=9$, $P=\mathrm{NS}$ ) and $>90 \%$ of measurable activity was associated with the cytosolic fraction. Indeed, no membrane-associated activity was detected in the cells exposed to $5 \mathrm{mM}$ D-glucose in five of nine experiments, but in four of nine experiments when membrane-associated activity was detected in the $5 \mathrm{mM}$ D-glucose sample, membrane-associated PKC activity was reduced in cells exposed to $50 \mathrm{mM}$ D-glucose (55.4 $\pm 3.1 \%$ control, $n=4, P<0.05$ ) but not in cells exposed to 50 $\mathrm{mM}$ L-glucose $(82.0 \pm 56.5 \%$ control, $n=4, P=\mathrm{NS})$. levels of cellular cGMP reflected tonic cellular NO activity. L-NAME $\left(10^{-8}-10^{-6} \mathrm{M}\right)$ decreased basal cGMP in a concentration-dependent fashion in $5 \mathrm{mM}$-glucose (Fig. 5, open circles) and exhibited additivity with $50 \mathrm{mM}$ D-glucose at $10^{-8} \mathrm{M}$ and $10^{-7} \mathrm{M}$ (Fig. 5, open triangles). Both 100 (Fig. 5, open squares) and $300 \mathrm{mM}$ D-glucose (Fig. 5, closed squares) lowered cGMP similar to the highest tested concentration of L-NAME $\left(10^{-6} \mathrm{M}\right)$ without exhibiting additivity. The effect of L-NAME on cGMP was evident in 20 min (data not shown), overcome by the addition of $10 \mathrm{mM}$-arginine (the NOS substrate for which L-NAME is a stereospecific competitive inhibitor, Fig. 5, inset), and reversed in $10 \mathrm{~min}$ by $1 \mu \mathrm{M} \mathrm{SNP}$, which chemically generates NO independent of NOS (cGMP in $5 \mathrm{mM}$ D-glucose, $5 \mathrm{mM}$ D-glucose $+1 \mu \mathrm{M}$ L-NAME, $5 \mathrm{mM}$ D-glucose $+1 \mu \mathrm{M}$ SNP, and $5 \mathrm{mM}$ D-glucose $+1 \mu \mathrm{M}_{\mathrm{L}-\mathrm{NAME}}+1 \mu \mathrm{M}$ SNP, were, respectively, $132.0 \pm 10.1,69.9 \pm 10.6,142.2 \pm 27.0$, and $105.2 \pm 5.6 \mathrm{fmol} / \mathrm{min}$ per $\mathrm{mg}$ protein, all $P<0.05 \mathrm{vs} .5 \mathrm{mM}$ D-glucose $+1 \mu \mathrm{M}$ L-NAME only). The relationship between D-glucose metabolism, NOS, and cGMP was further explored by testing whether SNP could acutely $(\leq 10 \mathrm{~min}$ ) reverse the near maximal effect of D-glucose. SNP $(1 \mu \mathrm{M})$ had no effect on

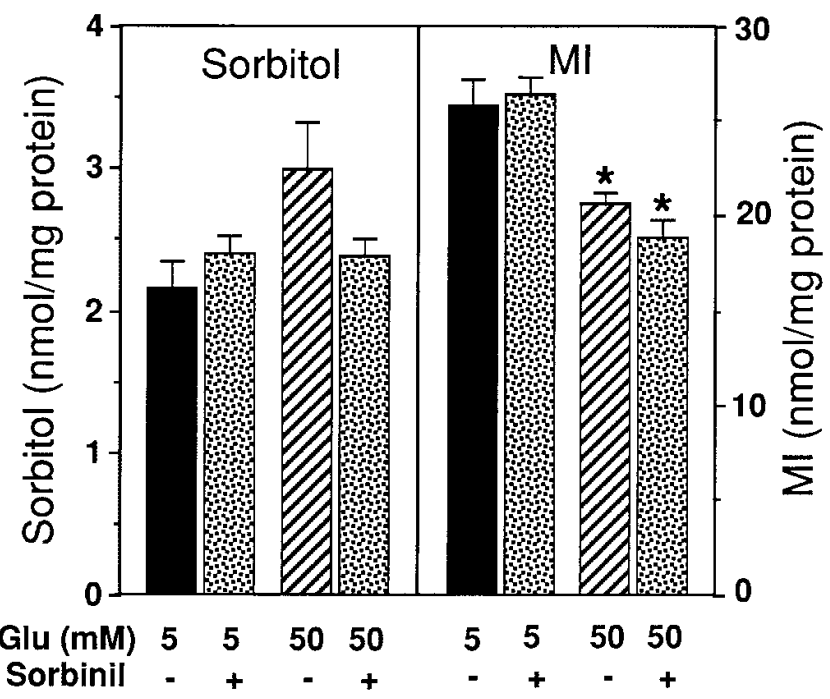

Figure 2. Effect of AR inhibitor sorbinil on sorbitol and MI in SHSY5Y cells. Cells were cultured in 5 or $50 \mathrm{mM}$ D-glucose $(\mathrm{Glu}) \pm 10$ $\mu \mathrm{M}$ sorbinil for $6 \mathrm{~d}(n=3$ replicate measures within a single experiment). Results were confirmed in an independent experiment except that the sorbitol content in $50 \mathrm{mM}$ D-glucose was statistically significantly greater than in the $5 \mathrm{mM}$ D-glucose. ${ }^{*} P<0.05$ vs. respective $5 \mathrm{mM}$ D-glucose control. 


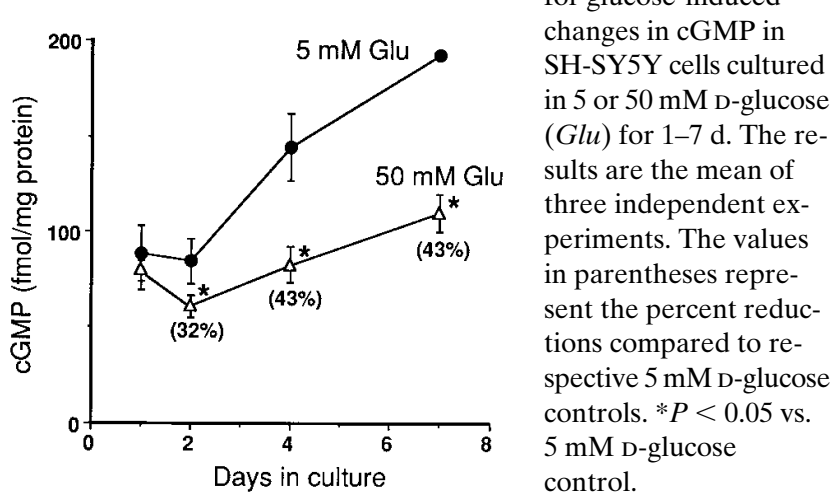

cGMP in the presence of $5 \mathrm{mM}$ D-glucose (Fig. 6, solid bars), but acutely raised cGMP in $50 \mathrm{mM}$ D-glucose (Fig. 6, hatched bars) to levels approximating the $5 \mathrm{mM}$ D-glucose control. Moreover, $10 \mu \mathrm{M}$ SNP raised cGMP levels above the $5 \mathrm{mM}$ D-glucose control in cells cultured in 5 and $50 \mathrm{mM}$ D-glucose (Fig. 6, stippled bars). These data are consistent with the hypothesis that NO acutely modulates cGMP production in SH-SY5Y cells, and that elevated levels of D-glucose progressively decrease cGMP production predominantly through an indirect NO-mediated effect on guanylyl cyclase. This contention is further supported by the observation that $\mathrm{D}$-glucose decreased $\mathrm{NO}_{2}$ appearance in the cell culture medium in a dose-

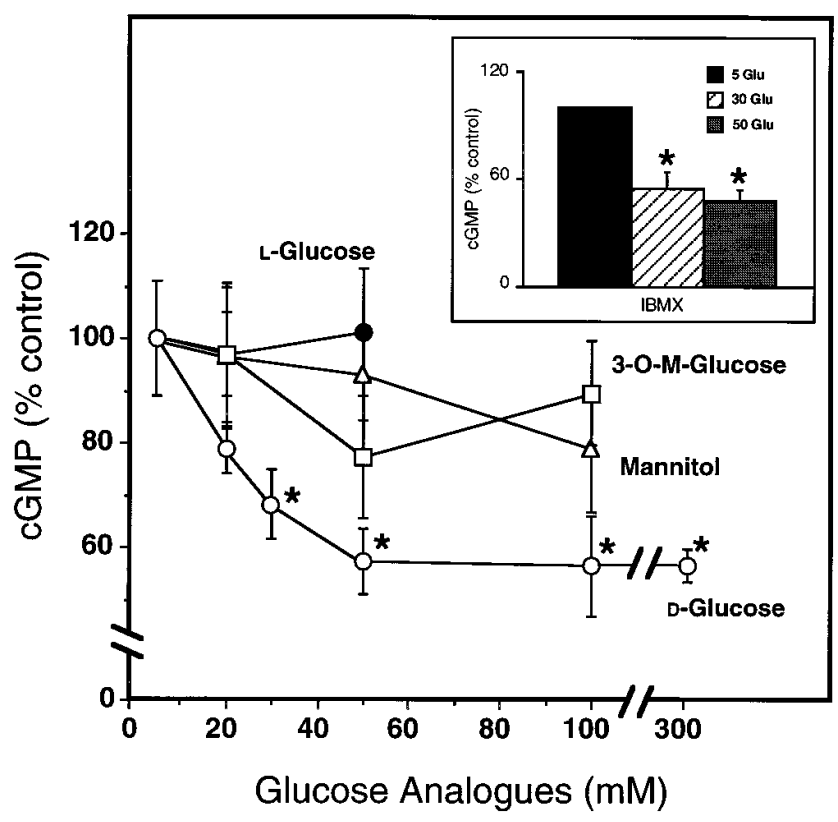

Figure 4. Concentration dependency of effects of D-glucose and nonmetabolized glucose analogues on cGMP levels in SH-SY5Y cells. Cells were cultured for $4 \mathrm{~d}$ in 5-300 mM D-glucose (open circles) or $5 \mathrm{mM}$ D-glucose media containing 15,45 , and $95 \mathrm{mM}$ L-glucose, $3-O$ methylglucose or mannitol. The results are 10 replicate measurements from two independent experiments. (Inset: Effect of IBMX on D-glucose-induced reduction in cGMP. Cells were cultured in 5, 30, or $50 \mathrm{mM}$ D-glucose for $5 \mathrm{~d}$ before transfer to new medium $\pm 500 \mu \mathrm{M}$ IBMX for $15 \min$ [ $n=4$ replicate measures within a single experiment with confirmation in an independent experiment]). ${ }^{*} P<0.05$ vs. $5 \mathrm{mM}$ D-glucose control.

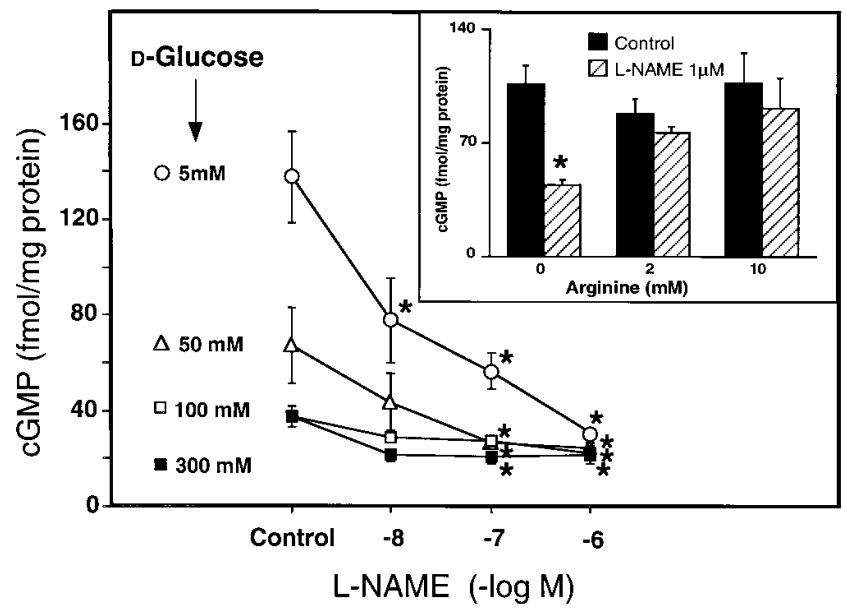

Figure 5. Effect of L-NAME on the D-glucose-induced decrease in cGMP levels in SH-SY5Y cells cultured for $4 \mathrm{~d}$ in 5-300 mM D-glucose and $0-10^{-6} \mathrm{M}$ L-NAME $(n=4$ replicate measures within a single experiment with confirmation in an independent experiment.) (Inset: Effect of L-arginine on the L-NAME-induced decrease in cGMP. Cells were cultured in $5 \mathrm{mM}$ D-glucose and $1 \mu \mathrm{M} \mathrm{L}-\mathrm{NAME}$ for $5 \mathrm{~d} \pm 2$ or $10 \mathrm{mM} \mathrm{L}$-arginine for the last $2 \mathrm{~d}$; the results were confirmed in an independent experiment). $* P<0.05$ vs. respective controls without L-NAME.

dependent fashion. SH-SY5Y cells were cultured for $7 \mathrm{~d}$ in 5 , 30 , or $50 \mathrm{mM}$ D-glucose. $\mathrm{NO}_{2}$ appearance in the medium over the last $24 \mathrm{~h}$ was $5.28 \pm 0.43,4.11 \pm 0.41$, and $2.97 \pm 0.39 \mathrm{nmol} / \mathrm{mg}$ protein in 5, 30, and $50 \mathrm{mM}$ D-glucose, respectively $(n=3, P<$ 0.05 for 5 vs. both 30 and $50 \mathrm{mM}$ D-glucose, with similar results replicated in two additional independent experiments).

Role of PKC and MI depletion in the depression of $c G M P$ by $D$-glucose. The near maximal depression of basal cGMP by $50 \mathrm{mM}$ D-glucose was acutely reversed by the PKC agonists $\operatorname{DiC}_{8}(50 \mu \mathrm{M} \times 2 \mathrm{~h})$ and TPA $(100 \mathrm{nM} \times 10 \mathrm{~min}$ or $2 \mathrm{~h})($ Fig. 7 , hatched bars), which did not affect cGMP in $5 \mathrm{mM}$ D-glucose (Fig. 7, solid bars) despite translocation of PKC to the membrane fraction (that raised membrane-associated $\mathrm{PKC}>$ fivefold; data not shown). Conversely, exposure to $1 \mu \mathrm{M}$ TPA for $24 \mathrm{~h}$ (which depressed cytosolic and membrane-associated PKC activity to undetectable levels; data not shown) decreased cGMP in $5 \mathrm{mM}$ (Fig. 7, compare open bar with solid

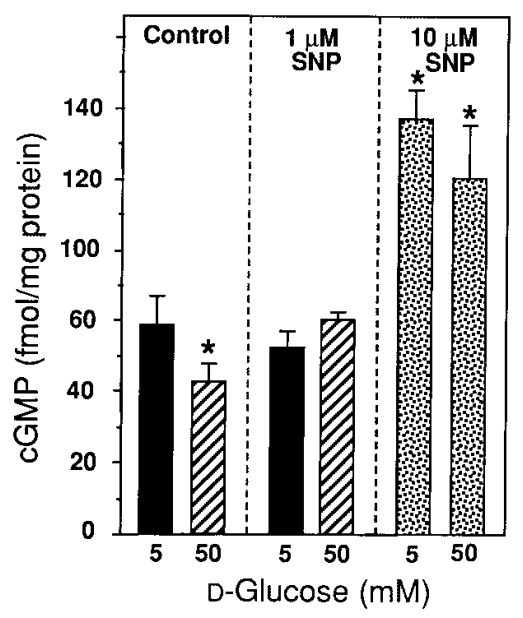

Figure 6. Effect of SNP on D-glucose-induced decrease in cGMP in SH-SY5Y cells cultured for $4 \mathrm{~d}$ in 5 or 50 $\mathrm{mM}$ D-glucose and incubated \pm 1 or $10 \mu \mathrm{M}$ SNP for $10 \min (n=4$ replicate measures within a single experiment with confirmation in an independent experiment). The results were confirmed in an independent experiment. $* P<0.05$ vs. $5 \mathrm{mM}$ D-glucose controls. 


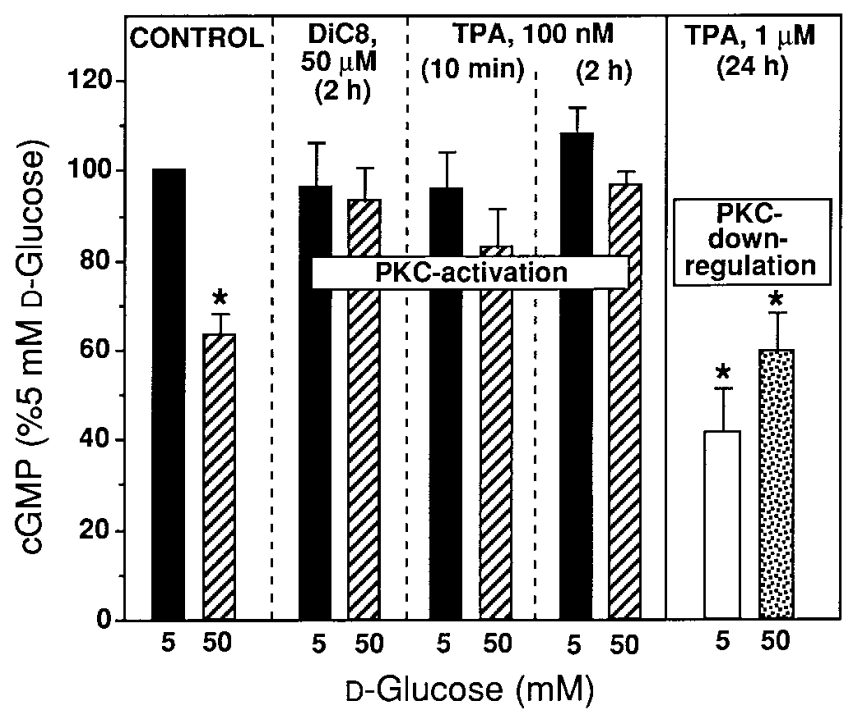

Figure 7. Effect of PKC-activation and -downregulation on D-glucose-induced decrease in cGMP. Cells were cultured for $4 \mathrm{~d}$ in 5 or 50 $\mathrm{mM}$ D-glucose $\pm \mathrm{DiC}_{8}$ or TPA as indicated $(n=4$ replicate measures within a single experiment with confirmation in an independent experiment). ${ }^{*} P<0.05$ vs. $5 \mathrm{mM}$ D-glucose controls.

bar on left) but not $50 \mathrm{mM}$ (Fig. 7, compare stippled bar with hatched bar on left) D-glucose. Calphostin C, a specific PKC inhibitor, decreased cGMP levels in $5 \mathrm{mM}$ (Fig. 8, solid bars) but not $50 \mathrm{mM}$ (Fig. 8, hatched bars) D-glucose, while SNP $(1 \mu \mathrm{M} \times$ $10 \mathrm{~min}$ ) reversed the effect of $50 \mathrm{mM}$-glucose or calphostin $\mathrm{C}$, acutely returning cGMP levels to that of the $5 \mathrm{mM}$-glucose control (Fig. 8, open bars). Higher concentrations of SNP $(10 \mu \mathrm{M})$ elevated cGMP to the same higher levels in both $5 \mathrm{mM}$

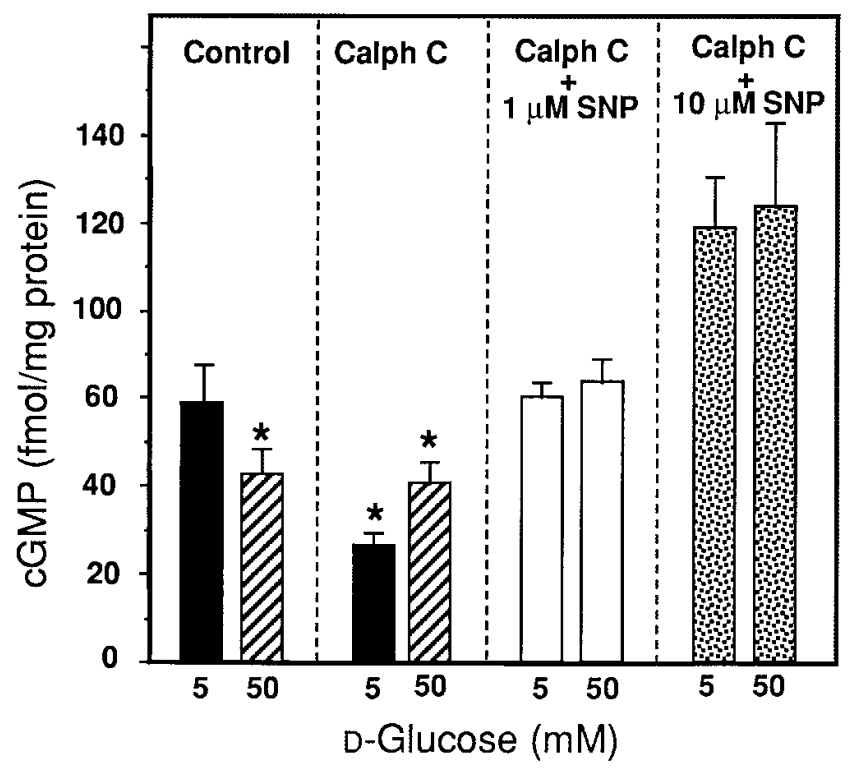

Figure 8. Effect of calphostin C and SNP on D-glucose-induced decrease in cGMP in cells cultured for $4 \mathrm{~d}$ in 5 or $50 \mathrm{mM} \mathrm{D}$-glucose. Calphostin C or SNP was added for the last $2 \mathrm{~h}$ or $10 \mathrm{~min}$, respectively ( $n=4$ replicate measures within a single experiment with confirmation in an independent experiment). $* P<0.05$ vs. $5 \mathrm{mM}$ D-glucose control. and $50 \mathrm{mM}$ D-glucose (Fig. 8, stippled bars). These studies suggest that the near maximal effect of $50 \mathrm{mM}$-glucose on cGMP is mediated by one or more D-glucose-sensitive fractions of PKC (38) that, within a critical range of activity, modulate NOS.

Supplementation of the DMEM-10\% BCS culture medium with $500 \mu \mathrm{M}$ MI partially corrected PI synthase inhibition (expressed as CDP-DG accumulation [Fig. 9, left]) and completely corrected near maximal cGMP depression (Fig. 9, right) in $50 \mathrm{mM}$-glucose without affecting either parameter in $5 \mathrm{mM}$-glucose (data not shown) strongly implicating MI depletion as a mediator of these D-glucose effects. Conversely, MI-depleted medium reproduced the near maximal effect of $50 \mathrm{mM}$ D-glucose on cGMP: cGMP levels after $7 \mathrm{~d}$ culture in serum-free DMEM-SHTE (25) and $5 \mathrm{mM}$ D-glucose with normal $(40 \mu \mathrm{M})$ or reduced $(0.1 \mu \mathrm{M})$ MI were $49.3 \pm 4.5$ and $33.2 \pm 3.4 \mathrm{fmol} / \mathrm{mg}$ protein, respectively, $(n=4, P<0.05$, with identical results in a second independent experiment). The reduction of cGMP induced by MI-deficient DMEM-SHTE was acutely reversed by TPA: cGMP in $40 \mu \mathrm{M}$ and $0.1 \mu \mathrm{M}$ MI for $7 \mathrm{~d}$ were, after exposure to $100 \mathrm{nM}$ TPA for $10 \mathrm{~min}, 49.0 \pm 7.3$ and $47.4 \pm 6.5 \mathrm{fmol} / \mathrm{mg}$ protein, respectively, (both $P=\mathrm{NS}$ vs. $40 \mu \mathrm{M}$ MI without TPA). On the other hand, $10 \mu \mathrm{M}$ sorbinil, which did not affect D-glucose-induced MI depletion (see above), did not alter cGMP content in either $5 \mathrm{mM}$ or $50 \mathrm{mM}$ D-glucose (respectively, $112.0 \pm 7.6$ and $86.3 \pm 5.7 \mathrm{fmol} / \mathrm{mg}$ protein $[P<0.05]$ in the absence of sorbinil; and 107.5 \pm 2.5 and $92.5 \pm 6.9 \mathrm{fmol} / \mathrm{mg}$ protein $[P<0.05]$ in the presence of sorbinil, $P=\mathrm{NS} \pm$ sorbinil). These data support the view that the effect of elevated $\mathrm{D}$-glucose on cGMP production in SH-SY5Y cells is mediated by MI depletion and inhibition of PI synthase by mass action, leading to decreased PI turnover and a reduction in a critical component of basal PKC activation that modulates basal NOS activity. However, in contrast to rat peripheral nerve $(13,15,16)$, SH-SY5Y cells exhibit low AR activity, and, accordingly, neither D-glucose-induced MI depletion nor its consequences were corrected by $\operatorname{AR}$ inhibition $(19,35)$.

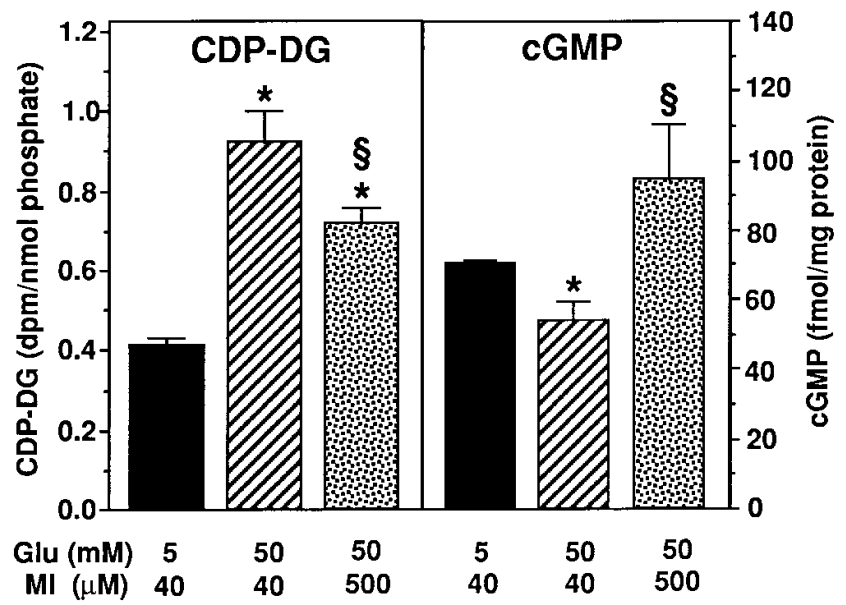

Figure 9. Effect of MI supplementation on D-glucose-induced changes in CDP-DG and cGMP. Cells were cultured for $5 \mathrm{~d}$ in 5 or 50 $\mathrm{mM}$ D-glucose $(G l u)$ with $40 \mu \mathrm{M}$ or $500 \mu \mathrm{M}$ MI. These results from four replicate samples were confirmed in an independent experiment of the same size. ${ }^{*} P<0.05$ vs. respective $5 \mathrm{mM}$ D-glucose controls. ${ }^{\S} P<0.05$ versus respective $50 \mathrm{M}$ D-glucose controls. 


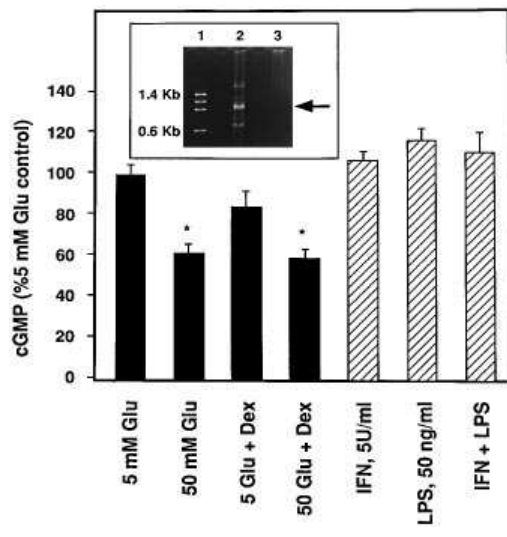
cate samples were confirmed in an independent experiment of the same size. $* P<0.05$ vs. respective $5 \mathrm{mM}$ D-glucose controls. (Inset: Ethidium bromide stained PAGE of RT-PCR products amplified from total RNA from SH-SY5Y cells cultured in $5 \mathrm{mM}$ D-glucose using primers specific for human ncNOS [lane 2] or human iNOS [lane 3]. Lane 1 contains molecular weight standards and arrow indicates the predicted $\sim 900$ bp size cDNA for ncNOS and iNOS).

Characterization of NOS in SH-SY5Y cells. The presence of ncNOS but not iNOS mRNA in SH-SY5Y cells was implied by an $\sim 900$ bp product amplified from SH-SY5Y reversetranscribed total RNA using primers specific for human nc-NOS (Fig. 10, inset, lane 2). A number of contaminating minor bands (some of which are shown) were of the predicted size for misprimed products. No products were observed after RT-PCR using the iNOS primers (Fig. 10, inset, lane 3). Consistent with the absence of iNOS mRNA, SH-SY5Y cells also exhibited little iNOS-like enzymatic activity since dexamethasone (2.5 $\mu \mathrm{M}$ for $2 \mathrm{~d}$ ), which suppresses iNOS induction (47), failed to modify basal or maximally D-glucose-inhibited cGMP levels (Fig. 10), and the addition of IFN- $\gamma$ (5 U/ml), LPS (50 ng/ $\mathrm{ml}$ ), or their combination, which induce iNOS (47), failed to increase cGMP levels (Fig. 10).

\section{Discussion}

A recent report from this laboratory implicating NO deficiency in the slowing of nerve conduction in the acutely streptozotocin-diabetic rat (13) combined with other recent reports of NO defects in diabetes $(7-14,48,49)$ prompted the present examination of the effect of D-glucose on NO-dependent cGMP levels in cultured human SH-SY5Y neuroblastoma cells. These well-differentiated neuronal cells selectively subcloned from the SKN-SH neuroblastoma (50) are commonly employed to study neuronal metabolism and signal transduction (51), in this case the relationship of D-glucose and MI metabolism to PKC and NO-dependent cGMP.

The progressive rise in cGMP after subculturing in $5 \mathrm{mM}$ D-glucose most likely represents progression of SH-SY5Y cells from $G_{0}$ through $G_{1}(52)$. The effects of elevated ambient D-glucose levels on cGMP were time- and dose-dependent, with an $\mathrm{IC}_{50}$ of $\sim 30 \mathrm{mM}$ and near maximal inhibition at $\sim 50$ $\mathrm{mM}$ D-glucose. These parameters lie within the general concentration range and duration of physiologic hyperglycemia that produces NO-related nerve conduction slowing in acute experimental diabetes (13). The effects of 30-50 mM D-glucose were physiologically and metabolically specific since they were unaccompanied by obvious changes in cell viability, growth, or morphology and were not reproduced by equimolar concentrations of nonmetabolized glucose analogues. Production rather than degradation of cGMP was altered since the effect of $50 \mathrm{mM}$ D-glucose persisted in the presence of the phosphodiesterase inhibitor IBMX. The D-glucose effect on cGMP appears to be mediated by NO, a known regulator of neuronal guanylyl cyclase $(1,2)$ : (a) L-NAME, a stereospecific L-arginine analogue that competitively inhibits NOS, reproduced the effect of D-glucose in a dose-dependent, L-arginine-sensitive manner without exhibiting additivity at maximal concentrations; (b) SNP, a chemical NO source, reversed the effects of $50 \mathrm{mM}$ D-glucose and L-NAME on cGMP, arguing against direct effects of either agent on guanylyl cyclase (53); and (c) D-glucose decreased $\mathrm{NO}_{2}$ appearance in the cell culture medium in a dose-dependent fashion. The magnitude of the maximal reduction of basal NO-dependent cGMP by $50 \mathrm{mM}$ D-glucose was virtually identical to that invoked in glomerular hypertension in diabetes (12).

The effect of D-glucose on cGMP in SH-SY5Y cells appears to reflect $\mathrm{MI}$ depletion, impaired PI synthesis, and PKC inhibition. D-glucose decreased MI and raised CDP-DG in a dosedependent fashion $(17,26)$. Culture in MI-deficient SHTE medium reproduced and supplementation of DMEM with 500 $\mu \mathrm{M}$ MI overcame the effect of $50 \mathrm{mM}$ D-glucose on cGMP. Biochemical and pharmacological results support PKC as an important mediator of the effects of D-glucose and MI depletion on NO-dependent cGMP through regulation of ncNOS. Firstly, $50 \mathrm{mM}$ D-glucose appeared to decrease the very low basal level of membrane-associated PKC activity (54) and reduced PKC-dependent MARCKS phosphorylation. Short-term stimulation of PKC with TPA or $\operatorname{DiC}_{8}(55,56)$ overcame the effect of $50 \mathrm{mM}$ D-glucose on cGMP. Conversely, downregulation of PKC with TPA $(57,58)$ or its inhibition by calphostin $\mathrm{C}$ (59) reproduced, but did not add to, the effect of $50 \mathrm{mM} \mathrm{D-glu-}$ cose. Similarly, SNP, which reversed the reduction of cGMP by $50 \mathrm{mM}$ D-glucose, also overcame the effect of calphostin C. Finally, the effect of MI depleted media on cGMP was reversed by PKC activation with TPA (Thomas, T.P., H. Shindo, and D.A. Greene. manuscript in preparation). These results do not, however, exclude the existence of alternative or parallel mechanisms (e.g., inositol-phosphate-regulated calcium or eicosanoid signaling) linking MI depletion to alterations in ncNOS activity, nor do they preclude a parallel subtle effect of PKC on guanylyl cyclase (53). Indeed, MI depletion has been shown to alter intracellular calcium (Thomas, T.P., H. Shindo, and D.A. Greene, manuscript in preparation) and D-glucose has been shown to alter eicosanoid production (Stevens, M.J., unpublished data) in SH-SY5Y cells. Thus, PKC signaling might represent only one of several redundant mechanisms by which ncNOS and NO action might be metabolically regulated in SH-SY5Y cells by D-glucose and phosphoinositide (60).

The observation that $\mathrm{D}$-glucose impairs basal $\mathrm{NO}$ activity in SH-SY5Y cells via MI and PKC add to a growing chain of evidence linking D-glucose to DAG and PKC regulation (16-19, $36-41,61)$, on the one hand, and PKC activation to NOS regulation $(47,62-70)$ on the other. However, these views are at best complex and fragmentary, if not at times paradoxical and contradictory. Diabetes and/or elevated D-glucose levels have been reported to decrease MI and phosphoinositide-derived 
arachidonyl-DAG (18), PKC activity (16, 39), and/or PKCrelated cellular functions $(20,61)$ in some but not all tissues prone to diabetic complications. Yet detailed patterns of response may vary even within the same tissue. For example, sciatic nerve from untreated streptozotocin-diabetic rats exhibits diminished total and arachidonyl-DAG $(17,18)$, and increased activation (71) and phosphorylation (20) of (Na,K)-ATPase by exogenous PKC agonists, consistent with a diminished basal level of PKC-mediated phosphorylation of ( Na,K)-ATPase. In separate studies, diminished activation of PKC (72) and decreased total and cytoplasmic intrinsic PKC activity have been noted in streptozotocin-diabetic rat sciatic nerve (16), perhaps reflecting the reported discordance between measures of cellular PKC activity and its translocation $(73,74)$. In other tissues equally prone to diabetic complications, D-glucose appears to increase rather than decrease total DAG and PKC activation $(36,38,41,62)$. Recent studies in cultured human retinal pigment epithelial (RPE) cells suggest that diametrically opposite effects of D-glucose on phosphoinositide and DAG metabolism reflect varying levels of expression of AR and AR-induced MI depletion within the same cell type (19). In RPE cells with high intrinsic AR gene expression (75), the predominant effect of elevated ambient D-glucose is AR-mediated sorbitol accumulation, reciprocal MI depletion (35), inhibition of PI synthase by mass action (26), diminished phosphoinositide turnover, and depletion of basal and agonist-stimulated arachidonylDAG (19). In RPE cells with low-grade intrinsic AR expression (75), D-glucose increases phosphoinositide turnover and DAG levels (19). Analogously divergent effects of D-glucose on DAG and PKC signal transduction have been reported in retinal microvascular endothelial cells (76) and pericytes (39), that also differ in AR expression (77). Although not the focus of this report, the relationship between AR pathway activity and MI in SH-SY5Y cells may be different from either high or low AR-expressing RPE cells. Sorbitol accumulation in SH-SY5Y cells is low compared to high AR-expressing RPE cells (19), yet MI depletion nevertheless occurs albeit by an AR inhibitor-insensitive mechanism. It is tempting to speculate that MI depletion in SH-SY5Y cells may reflect competitive inhibition or another AR-independent interaction between D-glucose or a D-glucose metabolite with the Na-MI cotransporter $(42,78,79)$, which is now under investigation.

The relationship between PKC and NOS is equally complex. PKC activation has been reported to increase (62) or attenuate (63) ncNOS activity. The studies reported in this communication suggest that normal basal PKC activity is sufficient to promote normal basal ncNOS activity, but, within a critical range, inhibition of PKC by D-glucose-induced MI-depletion limits basal ncNOS activation. (A parallel relationship between basal PKC activity and basal $[\mathrm{Na}, \mathrm{K}]$-ATPase activity was reported in peripheral nerve from diabetic animals [80], and NO has also been reported recently to stimulate vascular $[\mathrm{Na}, \mathrm{K}]$-ATPase independent of cGMP [81]). Given that attenuation of ncNOS by PKC activation has been noted primarily when ncNOS was stimulated by other agonists $(47,69,70)$, the studies in this report suggest that PKC could tonically stimulate basal ncNOS activity yet nevertheless dampen the activation of ncNOS by other agonists. (PKC may also attenuate agonist-induced iNOS gene expression [82]). This relationship would complement the reported inverse bidirectional interactions between $\mathrm{NO}$ and PKC described in platelets, where NO inhibits agonist-induced phosphoinositide turnover, calcium mobilization, and PKC substrate phosphorylation while enhancing PKC substrate phosphorylation with calcium ionophore (83).

The effect of D-glucose on ncNOS could have significant implications for the pathogenesis of diabetic complications, particularly diabetic neuropathy (Fig. 11). Metabolic (84) and vascular $(13,76,85-87)$ factors have been invoked in the pathogenesis of diabetic neuropathy, but the interrelationships among these factors are poorly understood. In the diabetic rat, impairment of nerve blood flow and conduction velocity have been ascribed in part to activation of the AR pathway $(85,86$, 88). Moreover, NO deficiency has been implicated as a possible link between AR activation, vascular dysfunction (49), and slowing of nerve conduction (11). As a putative postganglionic, postsynaptic inhibitory neurotransmitter (5), neuronal NO would normally dampen sympathetic tone and endoneurial vascular resistance (which does not locally autoregulate [6]) in the maintenance of normal endoneurial perfusion (88), which accordingly would be impaired by postganglionic NO deficiency (Fig. 11). This contention is consistent with the recently reviewed evidence $(88,89)$ indicating that chemical sympathectomy essentially normalizes nerve blood flow in experimental diabetes to the same extent as peripheral vasodilators. ${ }^{3}$ A parallel inhibition by D-glucose of ncNOS in somatic myelinated peripheral neurons might also impair nerve conduction independent of ischemia through such potentially NOregulated processes as (Na,K)-ATPase activity (Fig. 11) (81, 92). Whether similar or different regulation of ecNOS or iNOS by $\mathrm{PKC}$ is also relevant to neuropathy or other diabetic complications remains to be determined (Fig. 11).

Possible mechanisms linking AR activation to NO deficiency include competition between AR and NOS for NADPH cofactor (13), and/or D-glucose-induced alterations in PKC activity, which in turn appears to modulate NOS. The present studies favor linkage by PKC rather than NADPH, although the latter is not entirely excluded in diabetic peripheral nerve in the rat where nerve sorbitol accumulation is more robust, where MI depletion also decreases nerve PKC activity (16), and where vascular as well as neural NOS could be involved. The apparent discrepancy in the potency of AR inhibition to correct D-glucose-induced, MI-related NO abnormalities in vivo and in vitro could simply reflect different mechanisms underlying MI depletion. Thus, AR-mediated MI depletion would predominate in intact nerve, which rapidly accumulates sorbitol in diabetes, while modest sorbitol accumulation in SH-SY5Y cells would unmask competitive inhibition of Na-MI cotransport by D-glucose as the predominant cause of MI depletion $(42,78,79)$.

In summary, hyperglycemia diminishes basal NO-dependent cGMP levels in human SH-SY5Y neuroblastoma cells in a dose-dependent fashion, mediated by a D-glucose-induced

3. A recent report (90) that dietary MI supplementation improved neither nerve conduction nor blood flow in streptozotocin-diabetic rats employed an unusually high MI dose previously shown to be nontherapeutic for nerve conduction in diabetic rats and neurotoxic to nondiabetic rats $(15,91)$, thereby explaining the apparent discrepancy with recently published and currently unpublished data demonstrating improved nerve conduction (13) and laser doppler blood flow (Stevens M.J., and D.A. Greene manuscript in preparation) in MI supplemented streptozotocin-diabetic rats. 


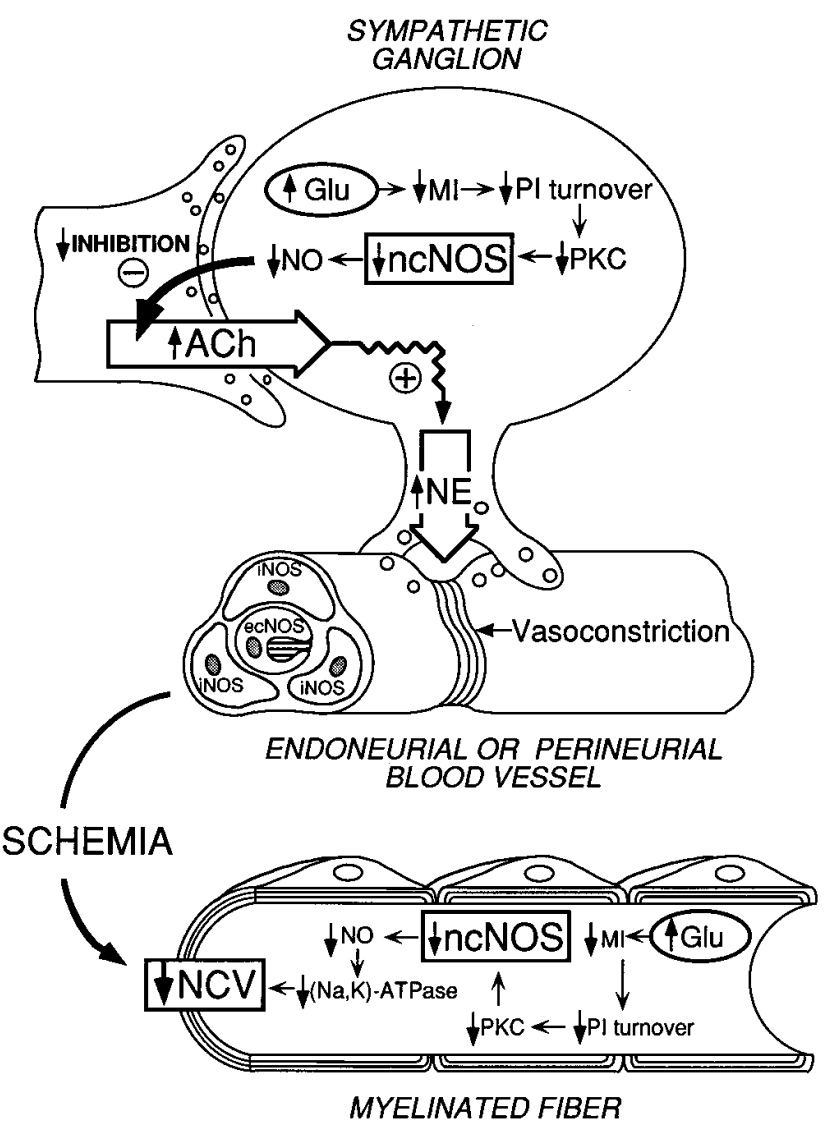

Figure 11. Pictorial model illustrating D-glucose $(G l u)$-induced inhibition of ncNOS in postganglionic sympathetic or myelinated peripheral somatic neurons leading to slowing of nerve conduction velocity $(\mathrm{NCV})$ in acute experimental diabetes. In this model, ncNOS is tonically regulated by PKC in both postganglionic sympathetic neurons (top) and in myelinated peripheral somatic neurons (bottom). In postganglionic sympathetic neurons, ncNOS sustains NO-mediated inhibition of pre-synaptic acetylcholine $(A C h)$ release (top left) to tonically dampen sympathetic tone (5). In large myelinated somatic neurons (bottom), ncNOS regulates putative NO-dependent functions such as (Na,K)-ATPase activity (81). This communication reports that human SH-SY5Y neuroblastoma cells cultured in D-glucose levels approximating those in the plasma of diabetic rats undergo MI depletion, inhibition of basal PI turnover, diminished PKC-mediated protein phosphorylation, and a reduction in NO synthesis by ncNOS. Extrapolation of these results in vivo would imply a decrease in NO-mediated inhibition of presynaptic acetylcholine release potentiating postganglionic norepinephrine $(N E)$ release, vasoconstriction of non-autoregulating endoneurial or perineurial microvessels (center), and endoneurial ischemia, which could decrease nerve conduction. At the same time, D-glucose-mediated inhibition of NO synthesis in peripheral somatic neurons (bottom) might additionally (or alternatively) slow nerve conduction by interfering with NO-dependent intraneuronal functions such as (Na,K)-ATPase (13, $81,92)$. Whether analogous D-glucose-mediated inhibition of endothelial ecNOS or smooth muscle iNOS (center) also contributes to ischemia and/or slowing of nerve conduction in diabetes remains to be established. This model provides a potential mechanistic link between metabolic responses of peripheral nerve to diabetes (e.g., MI depletion) through NO to endoneurial ischemia and slowed nerve conduction velocity, which now needs further exploration and clarification in vivo. decrease in MI content and PKC activity that in turn causes decreased ncNOS activity. A similar decrease in peripheral neuronal NO in vivo could at least in part explain impaired nerve conduction in diabetes through alterations in neurally regulated nerve blood flow, or by direct impairment of other NO and/or cGMP-regulated neuronal functions, e.g., (Na,K)ATPase activity $(35,81,92)$ (Fig. 11). By extrapolation, D-glucose-induced perturbations in other NOS isoforms could extend to diabetic complications other than neuropathy, including diabetic glomerulopathy, where thromboxane-mediated PKC activation impairs NO generation and action (12), macrovascular disease (49), where glucose-mediated NO-deficiency appears to inhibit $(\mathrm{Na}, \mathrm{K})$-ATPase activity $(81,93)$, and diabetic retinopathy, where NO has been implicated in pericyte relaxation (94) and where NO deficiency could reduce retinal blood flow (95).

\section{Acknowledgments}

We thank Dr. Ron Koenig for his consultation and support as Director of the Molecular Biology Core of the Michigan Diabetes Research and Training Center. We also thank Mark Warnock, Lisa Beyer, and Chris Antczak for technical support, Sarah Lattimer and Dr. David Misek for editorial assistance, and Pat Wilson for secretarial assistance.

The study was supported in part by the United States Public Health Service grant R01-DK38304 (D.A. Greene, and T.P. Thomas) and the Michigan Diabetes Research and Training Center.

\section{References}

1. Schmidt, H.H., and U. Walter. 1994. NO at work. Cell. 78:919-925.

2. Sessa, W.C. 1994. The nitric oxide synthase family of proteins. J. Vasc. Res. 31:131-143.

3. Zhang, J., V.L. Dawson, T.M. Dawson, and S.H. Snyder. 1994. Nitric oxide activation of poly(ADP-ribose) synthetase in neurotoxicity. Science (Wash. DC). 263:687-689.

4. Keaney, J.F., Jr., D.I. Simon, J.S. Stamler, O. Jaraki, J. Scharfstein, J.A. Vita, and J. Loscalzo. 1993. NO forms an adduct with serum albumin that has endothelium-derived relaxing factor-like properties. J. Clin. Invest. 91:15821589 .

5. Bult, H., G.E. Boeckxstaens, P.A. Pelckmans, F.H. Jordaens, Y.M. Van Maercke, and A.G. Herman. 1990. Nitric oxide as an inhibitory non-adrenergic non-cholinergic neurotransmitter. Nature (Lond.). 345:346-347.

6. Low, P.A., and R.R. Tuck. 1984. Effects of blood pressure, respiratory acidosis and hypoxia on blood flow in the sciatic nerve of the rat. J. Physiol. 347: $513-524$.

7. Oyama, Y., H. Kawasaki, Y. Hattori, and M. Kanno. 1986. Attenuation of endothelium-dependent relaxation in aorta from diabetic rats. Eur. J. Pharmacol. 132:75-78.

8. Abiru, T., Y. Watanabe, K. Kamata, N. Miyata, and Y. Kasuya. 1990. Decrease in endothelium-dependent relaxation and levels of cyclic nucleotides in aorta from rabbits with alloxan-induced diabetes. Res. Commun. Chem. Pathol. Pharmacol. 68:13-25.

9. Tesfamariam, B., M.L. Brown, and R.A. Cohen. 1991. Elevated glucose impairs endothelium-dependent relaxation by activating protein kinase C. $J$. Clin. Invest. 87:1643-1648.

10. Chang, K.S., and W.C. Stevens. 1992. Endothelium-dependent increase in vascular sensitivity to phenylephrine in long-term streptozotocin diabetic rat aorta. Br. J. Pharmacol. 107:983-990.

11. Wang, Y.X., D.P. Brooks, and R.M. Edwards. 1993. Attenuated glomerular cGMP production and renal vasodilation in streptozotocin-induced diabetic rats. Am. J. Physiol. 264:R952-R956.

12. Craven, P.A., R.K. Studer, and F.R. DeRubertis. 1994. Impaired nitric oxide-dependent cyclic guanosine monophosphate generation in glomeruli from diabetic rats. Evidence for protein kinase C-mediated suppression of the cholinergic response. J. Clin. Invest. 93:311-320.

13. Stevens, M.J., J. Dananberg, E.L. Feldman, S.A. Lattimer, M. Kamijo, T.P. Thomas, H. Shindo, A.A. Sima, and D.A. Greene. 1994. The linked roles of nitric oxide, aldose reductase and, $(\mathrm{Na}+, \mathrm{K}+)$-ATPase in the slowing of nerve conduction in the streptozotocin diabetic rat. J. Clin. Invest. 94:853-859.

14. Tilton, R.G., K. Chang, K.S. Hasan, S.R. Smith, J.M. Petrash, T.P. Misko, W.M. Moore, M.G. Currie, J.A. Corbett, M.L. McDaniel, et al. 1993. 
Prevention of diabetic vascular dysfunction by guanidines. Inhibition of nitric oxide synthase versus advanced glycation end-product formation. Diabetes. 42 : 221-232.

15. Greene, D.A., S. Lattimer-Greene, and A.A. Sima. 1989. Pathogenesis of diabetic neuropathy: role of altered phosphoinositide metabolism. Crit. Rev. Neurobiol. 5:143-219.

16. Kim, J., E.H. Rushovich, T.P. Thomas, T. Ueda, B.W. Agranoff, and D.A. Greene. 1991. Diminished specific activity of cytosolic protein kinase C in sciatic nerve of streptozocin-induced diabetic rats and its correction by dietary myo-inositol. Diabetes. 40:1545-1554.

17. Zhu, X., and J. Eichberg. 1990. A myo-inositol pool utilized for phosphatidylinositol synthesis is depleted in sciatic nerve from rats with streptozotocin-induced diabetes. Proc. Natl. Acad. Sci. USA. 87:9818-9822.

18. Zhu, X., and J. Eichberg. 1990. 1,2-diacylglycerol content and its arachidonyl-containing molecular species are reduced in sciatic nerve from streptozotocin-induced diabetic rats. J. Neurochem. 55:1087-1090.

19. Thomas, T.P., E.L. Feldman, J. Nakamura, K. Kato, M. Lien, M.J. Stevens, and D.A. Greene. 1993. Ambient glucose and aldose reductaseinduced myo-inositol depletion modulate basal and carbachol-stimulated inositol phospholipid metabolism and diacylglycerol accumulation in human retinal pigment epithelial cell culture. Proc. Natl. Acad. Sci. USA. 90:9712-9716.

20. Borghini, I., K. Geering, A. Gjinovci, C.B. Wollheim, and W.F. Pralong. 1994. In vivo phosphorylation of the $\mathrm{Na}, \mathrm{K}-\mathrm{ATPase}$ alpha subunit in sciatic nerves of control and diabetic rats: effects of protein kinase modulators. Proc. Natl. Acad. Sci. USA. 91:6211-6215.

21. Yorek, M.A., J.A. Dunlap, and B.H. Ginsberg. 1987. myo-Inositol metabolism in 41A3 neuroblastoma cells: effects of high glucose and sorbitol levels. J. Neurochem. 48:53-61.

22. Yorek, M.A., J.A. Dunlap, and E.M. Leeney. 1989. Effect of galactose and glucose levels and sorbinil treatment on myo-inositol metabolism and $\mathrm{Na}+-\mathrm{K}+$ pump activity in cultured neuroblastoma cells. Diabetes. 38:996-1004.

23. McKinney, M., C. Bolden, C. Smith, A. Johnson, and E. Richelson. 1990. Selective blockade of receptor-mediated cyclic GMP formation in N1E115 neuroblastoma cells by an inhibitor of nitric oxide synthesis. Eur. J. Pharmacol. 178:139-140.

24. Chaki, S., and T. Inagami. 1993. New signalling mechanism of angiotensin II in neuroblastoma neuro-2A cells: activation of soluble guanylyl cyclase via nitric oxide synthesis. Mol. Pharmacol. 43:603-608.

25. Pahlman, S., G. Meyerson, E. Lindgren, M. Schalling, and I. Johansson. 1991. Insulin-like growth factor I shifts from promoting cell division to potentiating maturation during neuronal differentiation. Proc. Natl. Acad. Sci. USA. 88:9994-9998.

26. Nakamura, J., M.A. Del Monte, D. Shewach, S.A. Lattimer, and D.A. Greene. 1992. Inhibition of phosphatidylinositol synthase by glucose in human retinal pigment epithelial cells. Am. J. Physiol. 262:E417-E426.

27. Yasuda, I., A. Kishimoto, S. Tanaka, M. Tominaga, A. Sakurai, and Y. Nishizuki. 1990. A synthetic peptide substrate for selective assay of protein kinase C. Biochem. Biophys. Res. Commun. 166:1220-1227.

28. Chakravaarthy, B.R., J. Isaacs, P. Morley, J.P. Durkin, and J.F. Whitfield. 1995. Stimulation of protein kinase $\mathrm{C}$ during $\mathrm{Ca}(2+)$-induced keratinocyte differentiation. Selective blockade of MARCKS phosphorylation by calmodulin. J. Biol. Chem. 270:1362-1368.

29. Smith, P.K., R.I. Krohn, G.T. Hermanson, A.K. Mallia, F.H. Gartner, M.D. Provenzano, E.K. Fujimoto, N.M. Goeke, B.J. Olson, and D.C. Klenk. 1985. Measurement of protein using bicinchoninic acid [published erratum appears in Anal. Biochem. 1987. 163:279]. Anal. Biochem. 150:76-85.

30. Green, L.C., D.A. Wagner, J. Glogowski, P.L. Skipper, J.S. Wishok, and S. R. Tannenbaum. 1982. Analysis of nitrate, nitrite, and $\left[{ }^{15} \mathrm{~N}\right]$ nitrate in biological fluids. Anal. Biochem. 126:131-138.

31. Fujisawa, H., T. Ogura, Y. Kurashima, T. Yokoyama, J. Yamashita, and H. Esumi. 1994. Expression of two types of nitric oxide synthase mRNA in human neuroblastoma cell lines. J. Neurochem. 63:140-145.

32. Janssens, S.P., A. Shimouchi, T. Quertermous, D.B. Bloch, and K.D. Bloch. 1992. Cloning and expression of a cDNA encoding human endotheliumderived relaxing factor/nitric oxide synthase [published erratum appears in $J$. Biol. Chem. 1992. 267:22694]. J. Biol. Chem. 267:14519-14522.

33. Bredt, D.S., P.M. Hwang, C.E. Glatt, C. Lowenstein, R.R. Reed, and S.H. Snyder. 1991. Cloned and expressed nitric oxide synthase structurally resembles cytochrome P-450 reductase. Nature (Lond.). 351:714-718.

34. Geller, D.A., C.J. Lowenstein, R.A. Shapiro, A.K. Nussler, M. Di Silvio, S.C. Wang, D.K. Nakayama, R.L. Simmons, S.H. Snyder, and T.R. Billiar. 1993. Molecular cloning and expression of inducible nitric oxide synthase from human hepatocytes. Proc. Natl. Acad. Sci. USA. 90:3491-3495.

35. Stevens, M.J., D.N. Henry, T.P. Thomas, P.D. Killen, and D.A. Greene. 1993. Aldose reductase gene expression and osmotic dysregulation in cultured human retinal pigment epithelial cells. Am. J. Physiol. 265:E428-E438.

36. Craven, P.A., C.M. Davidson, and F.R. DeRubertis. 1990. Increase in diacylglycerol mass in isolated glomeruli by glucose from de novo synthesis of glycerolipids. Diabetes. 39:667-674.

37. Wolf, B.A., J.R. Williamson, R.A. Easom, K. Chang, W.R. Sherman, and J. Turk. 1991. Diacylglycerol accumulation and microvascular abnormalities induced by elevated glucose levels. J. Clin. Invest. 87:31-38.
38. Inoguchi, T., R. Battan, E. Handler, J.R. Sportsman, W. Heath, and G.L. King. 1992. Preferential elevation of protein kinase C isoform beta II and diacylglycerol levels in the aorta and heart of diabetic rats: differential reversibility to glycemic control by islet cell transplantation. Proc. Natl. Acad. Sci. USA. 89:11059-11063.

39. de la Rubia, G., F.J. Oliver, T. Inoguchi, and G.L. King. 1992. Induction of resistance to endothelin-1's biochemical actions by elevated glucose levels in retinal pericytes. Diabetes. 41:1533-1539.

40. Williams, B., and R.W. Schrier. 1992. Characterization of glucoseinduced in situ protein kinase C activity in cultured vascular smooth muscle cells. Diabetes. 41:1464-1472.

41. Shiba, T., T. Inoguchi, J.R. Sportsman, W.F. Heath, S. Bursell, and G.L. King. 1993. Correlation of diacylglycerol level and protein kinase C activity in rat retina to retinal circulation. Am. J. Physiol. 265:E783-E793.

42. Greene, D.A., and S.A. Lattimer. 1982. Sodium- and energy-dependent uptake of myo-inositol by rabbit peripheral nerve. Competitive inhibition by glucose and lack of an insulin effect. J. Clin. Invest. 70:1009-1018.

43. Cammarata, P.R., H.Q. Chen, J. Yang, and T. Yorio. 1992. Modulation of myo-[3H]inositol uptake by glucose and sorbitol in cultured bovine lens epithelial cells. II. Characterization of high- and low-affinity myo-inositol transport sites. Invest. Ophthalmol. \& Visual Sci. 33:3572-3580.

44. Del Monte, M.A., R. Rabbani, T.C. Diaz, S.A. Lattimer, J. Nakamura, M.C. Brennan, and D.A. Greene. 1991. Sorbitol, myo-inositol, and rod outer segment phagocytosis in cultured hRPE cells exposed to glucose. In vitro model of myo-inositol depletion hypothesis of diabetic complications. Diabetes. 40: $1335-1345$.

45. Winegrad, A.I. 1987. Banting lecture 1986. Does a common mechanism induce the diverse complications of diabetes? Diabetes. 36:396-406.

46. Forstermann, U., J.S. Pollock, H.H. Schmidt, M. Heller, and F. Murad. 1991. Calmodulin-dependent endothelium-derived relaxing factor/nitric oxide synthase activity is present in the particulate and cytosolic fractions of bovine aortic endothelial cells. Proc. Natl. Acad. Sci. USA. 88:1788-1792.

47. Jun, C.D., H.J. Hoon-Ryu, J.Y. Um, T.Y. Kim, J.M. Kim, S.S. Kang, H.M. Kim, and H.T. Chung. 1994. Involvement of protein kinase $\mathrm{C}$ in the inhibition of nitric oxide production from murine microglial cells by glucocorticoid. Biochem. Biophys. Res. Commun. 199:633-638.

48. Kamata, K., N. Miyata, and Y. Kasuya. 1989. Impairment of endothelium-dependent relaxation and changes in levels of cyclic GMP in aorta from streptozotocin-induced diabetic rats. Br. J. Pharmacol. 97:614-618.

49. Cameron, N.E., and M.A. Cotter. 1992. Impaired contraction and relaxation in aorta from streptozotocin-diabetic rats: role of polyol pathway. Diabetologia. 35:1011-1019.

50. Ross, R.A., B.A. Spengler, and J.L. Biedler. 1983. Coordinate morphological and biochemical interconversion of human neuroblastoma cells. J. Natl. Cancer Inst. 71:741-747.

51. Fisher, S.K., A.M. Heacock, and B.W. Agranoff. 1992. Inositol lipids and signal transduction in the nervous system: an update. J. Neurochem. 58:18-38.

52. Siefert, W., and P.S. Rudland. 1974. Cyclic nucleotides and growth control in cultured mouse cells: correlation of changes in intracellular $3^{\prime}: 5^{\prime}$ cGMP concentration with a specific phase of the cell cycle. Proc. Natl. Acad. Sci. USA. 71:4920-4924.

53. Louis, J.C., M.O. Revel, and J. Zwiller. 1993. Activation of soluble guanylate cyclase through phosphorylation by protein kinase $\mathrm{C}$ in intact PC12 cells. Biochem. Biophys. Acta. 1177:299-306.

54. Thomas, T.P., R. Gopalakrishna, and W.B. Anderson. 1987. Hormoneand tumor promoter-induced activation or membrane association of protein kinase C in intact cells. Methods Enzymol. 141:399-411.

55. Kraft, A.S., and W.B. Anderson. 1983. Phorbol esters increase the amount of $\mathrm{Ca} 2+$, phospholipid-dependent protein kinase associated with plasma membrane. Nature (Lond.). 301:621-623.

56. Lapetina, E.G., B. Reep, B.R. Ganong, and R.M. Bell. 1985. Exogenous sn-1,2-diacylglycerols containing saturated fatty acids function as bioregulators of protein kinase C in human platelets. J. Biol. Chem. 260:1358-1361.

57. Rodriguez-Pena, A., and E. Rozengurt. 1984. Disappearance of Ca2+sensitive, phospholipid-dependent protein kinase activity in phorbol estertreated 3T3 cells. Biochem. Biophys. Res. Commun. 120:1053-1059.

58. Ballester, R., and O.M. Rosen. 1985. Fate of immunoprecipitable protein kinase $\mathrm{C}$ in $\mathrm{GH} 3$ cells treated with phorbol 12-myristate 13-acetate. J. Biol. Chem. 260:15194-15199.

59. Kobayashi, E., H. Nakano, M. Morimoto, and T. Tamaoki. 1989. Calphostin C (UCN-1028C), a novel microbial compound, is a highly potent and specific inhibitor of protein kinase C. Biochem. Biophys. Res. Commun. 159:548-553.

60. Nishizuka, Y. 1992. Intracellular signaling by hydrolysis of phospholipids and activation of protein kinase C. Science (Wash. DC). 258:607-614.

61. Greene, D.A., and S.A. Lattimer. 1986. Protein kinase C agonists acutely normalize decrease ouabain-inhibitable respiration in diabetic rabbit nerve. Implications for $(\mathrm{Na}, \mathrm{K})$-ATPase regulation and diabetic complications. Diabetes. 35:242-245.

62. Nakane, M., J. Mitchell, U. Forstermann, and F. Murad. 1991. Phosphorylation by calcium calmodulin-dependent protein kinase II and protein kinase C modulates the activity of nitric oxide synthase. Biochem. Biophys. Res. Com- 
mun. 180:1396-1402.

63. Bredt, D.S., C.D. Ferris, and S.H. Snyder. 1992. Nitric oxide synthase regulatory sites. Phosphorylation by cyclic AMP-dependent protein kinase, protein kinase $\mathrm{C}$, and calcium/calmodulin protein kinase; identification of flavin and calmodulin binding sites. J. Biol. Chem. 267:10976-10981.

64. Kawabe, J., Y. Ohsaki, and S. Onodera. 1992. Down-regulation of protein kinase $\mathrm{C}$ potentiates atrial natriuretic peptide-stimulated cGMP accumulation in vascular smooth-muscle cells. Biochem. Biophys. Acta. 1175:81-87.

65. Hortelano, S., A.M. Genaro, and L. Bosca. 1992. Phorbol esters induce nitric oxide synthase activity in rat hepatocytes. Antagonism with the induction elicited by lipopolysaccharide. J. Biol. Chem. 267:24937-24940.

66. Severn, A., M.J. Wakelam, and F.Y. Liew. 1992. The role of protein kinase $\mathrm{C}$ in the induction of nitric oxide synthesis by murine macrophages. Biochem. Biophys. Res. Commun. 188:997-1002.

67. Hortelano, S. A.M. Genaro, and L. Bosca. 1993. Phorbol esters induce nitric oxide synthase and increase arginine influx in cultured peritoneal macrophages. FEBS Lett. 320:135-139.

68. Bosca, L., and P.A. Lazo. 1994. Induction of nitric oxide release by MRC OX-44 (anti-CD53) through a protein kinase C-dependent pathway in rat macrophages. J. Exp. Med. 179:1119-1126.

69. Davda, R.K., L.J. Chandler, and N.J. Guzman. 1994. Protein kinase C modulates receptor-independent activation of endothelial nitric oxide synthase. Eur. J. Pharmacol. 266:237-244.

70. Murthy, K.S., J.G. Jin, and G.M. Makhlouf. 1994. Inhibition of nitric oxide synthase activity in dispersed gastric muscle cells by protein kinase C. Am. J. Physiol. 266:G161-G165.

71. Kim, J., H. Kyriazi, and D.A. Greene. 1991. Normalization of $\mathrm{Na}(+)-$ $\mathrm{K}(+)$-ATPase activity in isolated membrane fraction from sciatic nerves of streptozocin-induced diabetic rats by dietary myo-inositol supplementation in vivo or protein kinase C agonists in vitro. Diabetes. 40:558-567.

72. Borghini, I., A. Ania-Lahuerta, R. Regazzi, G. Ferrari, A. Gjinovci, C.B. Wollheim, and W.F. Pralong. 1994. Alpha, beta I, beta II, delta, and epsilon protein kinase $\mathrm{C}$ isoforms and compound activity in the sciatic nerve of normal and diabetic rats. J. Neurochem. 62:686-696.

73. Erne, P., N. Mazurek, C. Borner, J.F. Conscience, U. Eppenberger, and D. Fabbro. 1987. Translocation of protein kinase $\mathrm{C}$ is not required to inhibit the antigen-induced increase of cytosolic calcium in a mast cell line. Biochem. Biophys. Res. Commun. 143:252-259.

74. Diaz-Guerra, M.J., and L. Bosca. 1990. Lack of translocation of protein kinase $\mathrm{C}$ from the cytosol to the membranes in vasopressin-stimulated hepatocytes. Biochem. J. 269:163-168.

75. Henry, D.N., M. Del Monte, D.A. Greene, and P.D. Killen. 1993. Altered aldose reductase gene regulation in cultured human retinal pigment epithelial cells. J. Clin. Invest. 92:617-623.

76. King, G.L., S. Johnson, and G. Wu. 1990. Possible growth modulations involved in the pathogenesis of diabetic proliferative retinopathy. In Growth Factors in Health and Disease. B. Westermark, C. Betsholtz, and B. Hokfelt, editors. Excerpta Medica, New York. 303-317.

77. Akagi, Y., Y. Yajima, P.F. Kador, T. Kuwabara, and J.H. Kinoshita. 1984. Localization of aldose reductase in the human eye. Diabetes. 33:562-566.

78. Cammarata, P.R., and H.Q. Chen. 1994. Osmoregulatory alterations in myo-inositol uptake by bovine lens epithelial cells. Part 1: A hypertonicityinduced protein enhances myo-inositol transport. Invest. Ophthalmol. \& Visual Sci. 35:1223-1235

79. Mistry, K.P., A. Beyer-Mears, and F.P. Diecke. 1993. Mechanisms for
D-glucose inhibition of myo-inositol influx into rat lens. Diabetes. 42:1737-1744.

80. Lattimer, S.A., A.A. Sima, and D.A. Greene. 1989. In vitro correction of impaired $\mathrm{Na}+-\mathrm{K}+-\mathrm{ATPase}$ in diabetic nerve by protein kinase $\mathrm{C}$ agonists. Am. J. Physiol. 256:E264-E269.

81. Gupta, S., C. McArthur, C. Grady, and N.B. Ruderman. 1994. Stimulation of vascular $\mathrm{Na}(+)-\mathrm{K}(+)$-ATPase activity by nitric oxide: a cGMP-independent effect. Am. J. Physiol. 266:H2146-H2151.

82. Nakayama, I., Y. Kawahara, T. Tsuda, M. Okuda, and M. Yokoyama 1994. Angiotensin II inhibits cytokine-stimulated inducible nitric oxide synthase expression in vascular smooth muscle cells. J. Biol. Chem. 269:1162811633 .

83. Nguyen, B.L., M. Saitoh, and J.A. Ware. 1991. Interaction of nitric oxide and cGMP with signal transduction in activated platelets. Am. J. Physiol. 261:H1043-H1052.

84. Greene, D.A., A.A. Sima, M.J. Stevens, E.L. Feldman, and S.A. Lattimer. 1992. Complications: neuropathy, pathogenetic considerations. Diabetes Care. 15:1902-1925.

85. Cameron, N.E., M.A. Cotter, and P.A. Low 1991. Nerve blood flow in early experimental diabetes in rats: relation to conduction deficits. Am. J. Physiol. 261:E1-E8.

86. Cameron, N.E., M.A. Cotter, K. Ferguson, S. Robertson, and M.A. Radcliffe. 1991. Effects of chronic alpha-adrenergic receptor blockade on peripheral nerve conduction, hypoxic resistance, polyols, $\mathrm{Na}(+)-\mathrm{K}(+)$-ATPase activity, and vascular supply in STZ-D rats. Diabetes. 40:1652-1658.

87. Cameron, N.E., M.A. Cotter, and S. Robertson. 1992. Angiotensin converting enzyme inhibition prevents development of muscle and nerve dysfunction and stimulates angiogenesis in streptozotocin-diabetic rats. Diabetologia. 35:12-18.

88. Greene, D.A., A.A. Sima, M.J. Stevens, E.L. Feldman, P.D. Killen, D.N. Henry, T. Thomas, J. Dananberg, and S.A. Lattimer. 1993. Aldose reductase inhibitors: an approach to the treatment of diabetic nerve damage. Diabetes Metab. Rev. 9:189-217.

89. Stevens, M.J., E.L. Feldman, and D.A. Greene. 1995. The aetiology of diabetic neuropathy: the combined roles of metabolic and vascular defects. Dia betic Med. 12:566-579.

90. Cameron, N.E., M.A. Cotter, K.C. Dines, E.K. Maxfield, F. Carey, and D.J. Mirrlees. 1994. Aldose reductase inhibition, nerve perfusion, oxygenation and function in streptozotocin-diabetic rats: dose-response considerations and independence from a myo-inositol mechanism. Diabetologia. 37:651-663.

91. Greene, D.A., P.V. DeJesus, and A.I. Winegrad. 1975. Effects of insulin and dietary myo-inositol on impaired motor nerve conduction velocity in acute streptozotocin diabetes. J. Clin. Invest. 55:1326-1336.

92. Gupta, S., I. Sussman, C.S. McArthur, K. Tornheim, R.A. Cohen, and N.B. Ruderman. 1992. Endothelium-dependent inhibition of $\mathrm{Na}(+)-\mathrm{K}+$ ATPase activity in rabbit aorta by hyperglycemia. Possible role of endotheliumderived nitric oxide. J. Clin. Invest. 90:727-732.

93. Ghahary, A., S. Chakrabarti, A. A. Sima, and L.J. Murphy. 1991. Effect of insulin and statil on aldose reductase expression in diabetic rats. Diabetes. 40 1391-1396.

94. Haefliger, I.O., A. Zschauer, and D.R. Anderson. 1994. Relaxation of retinal pericyte contractile tone through the nitric oxide-cyclic guanosine monophosphate pathway. Invest. Ophthalmol. \& Visual Sci. 35:991-997.

95. Clermont, A.C., M. Brittis, T. Shiba, T. McGovern, G.L. King, and S.E. Bursell. 1994. Normalization of retinal blood flow in diabetic rats with primary intervention using insulin pumps. Invest. Ophthalmol. \& Visual Sci. 35:981-990. 